\title{
UNUSUAL PRESENTATION OF GIANT CELL TUMOR OF PHALANX
}

\author{
K. Ramkumar Reddy ${ }^{1}$, P. Sivananda², J. Venkateswarlu³, R. Jaisingh ${ }^{4}$
}

\section{HOW TO CITE THIS ARTICLE:}

K. Ramkumar Reddy, P. Sivananda, J. Venkateswarlu, R. Jaisingh. "Unusual Presentation of Giant Cell Tumor of Phalanx". Journal of Evolution of Medical and Dental Sciences 2015; Vol. 4, Issue 51, June 25;

Page: 8934-8937, DOI: $10.14260 /$ jemds/2015/1294

\begin{abstract}
A 13 year old girl presented with a painful and swollen left middle finger with no overlying skin abnormality. There was no history of past trauma. A radiograph showed a radiolucent lesion, within the middle phalanx, with surrounding cortical thinning. No new bone formation. Histological analysis reported benign cartilaginous lesion. With provisional diagnosis of Enchondroma, curettage and cortico-cancellous grafting was done. Over a 4 month duration, the graft absorbed and increase in swelling and brake in cortex. Suspecting a giant cell tumour of bone, amputation of finger through middle phalanx was done. Histology Specimen confirmed giant cell tumour. The patient had excellent hand function and has had no complications. BACKGROUND: Giant cell tumor commonly occurs in upper middle age group females at epiphyses of long bones. Occurrence in children and that of phalanges is a rare condition. Only $2 \%$ of all reported GCTs are found in the hand.[1]
\end{abstract}

KEYWORDS: Osteolytic lesion of phalanx, Unusual giant cell tumor, Osteoclastoma in young.

INTRODUCTION: The patient was initially presented as a common benign condition, supported by clinical, skeletal features and FNAC as enchondroma. But its recurrence and change its features made us to rethink the diagnosis and full specimen histopathology confirmed the diagnosis. Local recurrence following curettage and bone grafting in GCT has been reported to be as high as $90 \% .{ }^{[2]}$

CASE PRESENTATION: A 13-year-old female presented with swelling in middle of middle finger of left hand for last 4 months. There was no history of injury or any associated constitutional symptoms. The swelling had been gradually increasing in size with mild pain. The pain was dull, continuous, and limited to the site of the lesion. There was no history of acute episodes of pain.

Examination revealed localized swelling of middle phalanx of left middle finger with no tenderness in the affected area. There were no signs of inflammation. The skin over the lesion was mobile. The movements at the proximal and Distal inter Phalangeal joints of the middle finger were terminally restricted but pain free. There was no associated lymphadenopathy. Capillary refilling in the nail bed was good. Allen's test showed that both digital vessels were patent. There was no sensory deficit. Distal movements were present. Radiography showed expansile, osteolytic lobulated soap bubble appearance of the tumor involving proximal end of metaphysis as well as diaphysis of middle phalanx.

There was no breach of the articular surface of MP joint or any periosteal reaction. No other focus of the tumor was seen. Laboratory findings, including serum calcium, phosphorus, and alkaline phosphatase were within normal ranges. Cytological Findings on Fine-needle aspiration of the lesion was done and was shown as cartilaginous lesion, Enchondroma. In view this benignity we proceeded to curettage and bone grafting. Intra-op findings were it is a clear fluid filled in an expansile bony walled cyst. Cortical and cancellous graft was filled in the void and closed. Post-operative period was uneventful. After 3 months Patient presented again with increase in swelling and pain. X-ray shown 


\section{CASE REPORT}

the graft was absorbed and breech in cortex. In view of aggressiveness, Amputation of finger through proximal phalanx was done. Histopathology of specimen, confirmed osteoclastic giant cell tumor. The patient recovered well and no further complaints.

DISCUSSION: Giant cell tumor of phalanx though uncommon, in this case it presented as enchondroma. If malignant transformation of Enchondroma occurs, it is to chondrosarcoma is usual. The diagnosis of osteolytic lesions especially giant cell and its variants can be surprising and as they are fluid filled spaces it is difficult to get proper sample, by which cytological diagnosis also biased at times. Histology of the lesion revealed osteoid formation. Kumar and Tuli[3] and Dahlin et al..4] reported similar histological findings in their series, which should be taken cautiously against enchonroma.

CONCLUSION: Enchondroma later presenting as giant cell tumor is commonly thought of due to inadequate sample / site of FNAC but if rely on facts, a very rare possibility of transformation cannot be excluded.

\section{REFERENCES:}

1. Averill RM, Smith RJ, Campbell CJ. Giant cell tumours of the bones of the hand. J Hand Surg. 1980; 5: 39-50. [PubMed]

2. Athanasian EA, Wold LE, Amadio PC. Giant cell tumour of the bones of the hand. J Hand Surg. 1997; 22A: 91-98. [PubMed]

3. Kumar S, Tuli SM. Giant cell tumour of the middle phalanx of the left fifth finger. Int Surg. 1971; 55 (4): 288-292. [PubMed]

4. Dahlin DC (1996) Dahlins bone tumours: general aspects and data of 11, 087 cases, 5th edn. Lippincott-Raven, Philadelphia.

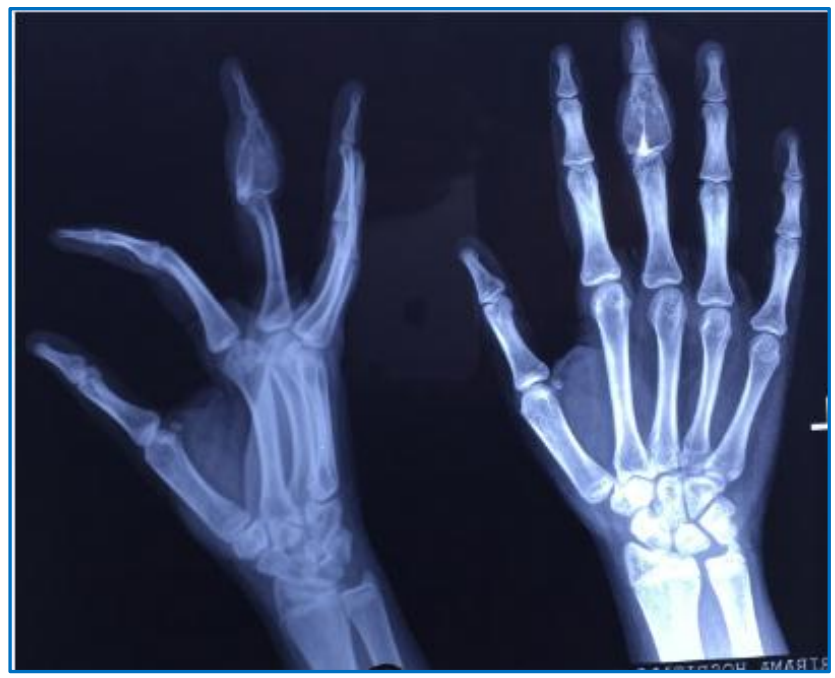

Fig. 1: 4 Months Post OP 


\section{CASE REPORT}

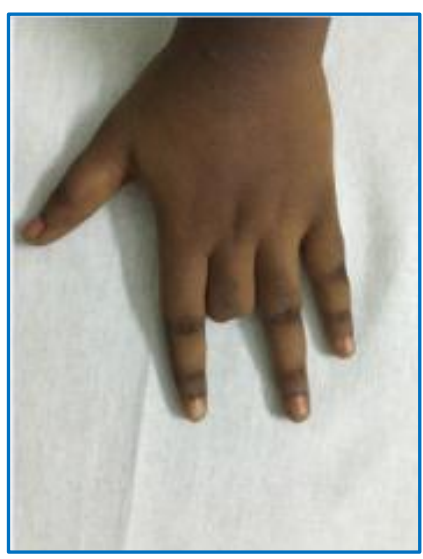

Fig. 2

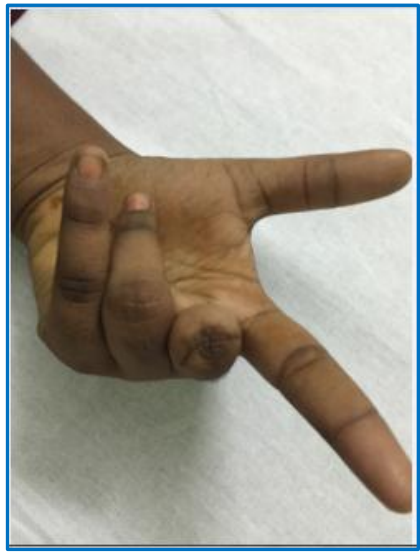

Fig. 4

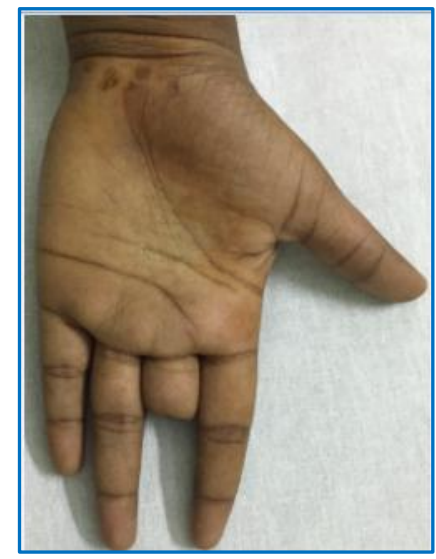

Fig. 3

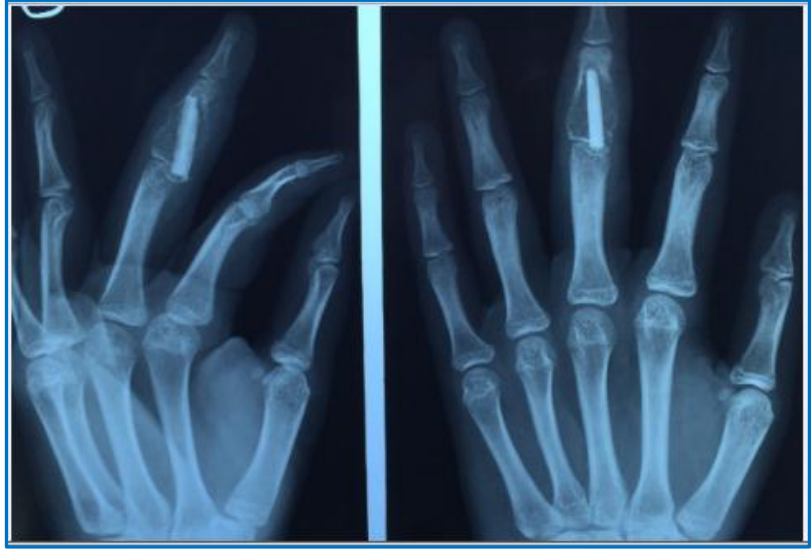

Fig. 5: POST OP

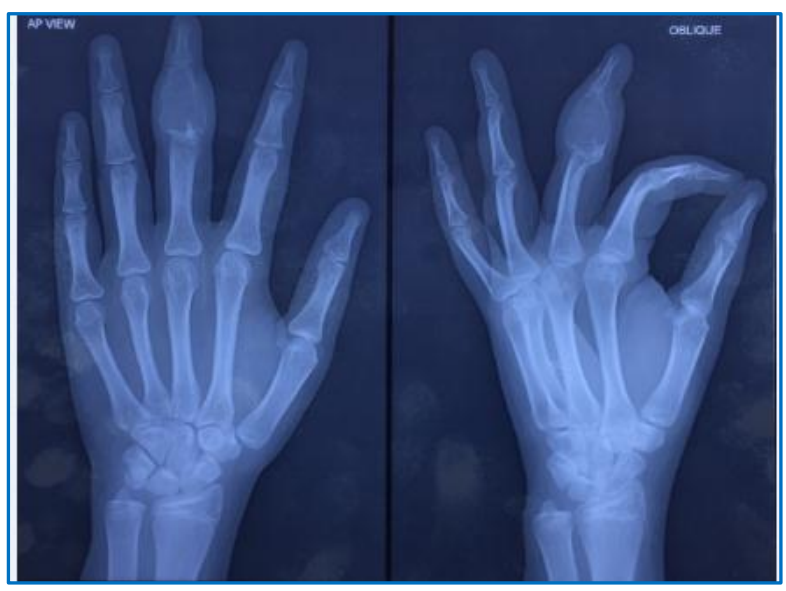

Fig. 6: Pre OP 


\section{AUTHORS:}

1. K. Ramkumar Reddy

2. P. Sivananda

3. J. Venkateswarlu

4. R. Jaisingh

\section{PARTICULARS OF CONTRIBUTORS:}

1. Associate Professor, Department of Orthopaedics, Kakateya Medical College, Warangal.

2. Associate Professor, Department of Orthopaedics, Andhra Medical College, Vizag.

3. Associate Professor, Department of Orthopaedics, Kakateya Medical College, Warangal.

FINANCIAL OR OTHER COMPETING INTERESTS: None
4. Assistant Professor, Department of Orthopaedics, Kakateya Medical College, Warangal.

\section{NAME ADDRESS EMAIL ID OF THE} CORRESPONDING AUTHOR:

Dr. K. Ramkumar Reddy, \# 6-2-337, Opp. Vijaya Talkies, Hanamkonda, Warangal.

Telangana.

E-mail: krkreddy2009@gmail.com

Date of Submission: 13/05/2015.

Date of Peer Review: 14/05/2015.

Date of Acceptance: 19/06/2015.

Date of Publishing: 25/06/2015. 